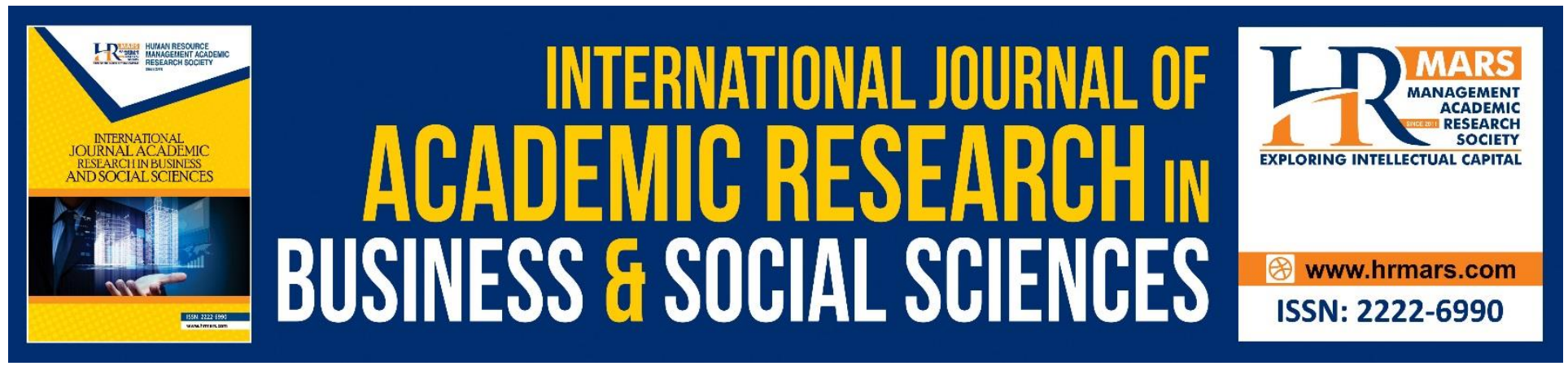

\title{
The Relationship between Students Satisfaction and their Academic Performance among Public Relations Degree Students in UiTM Alor Gajah Melaka
}

Abdul Rauf Ridzuan, Mohd Khairornizam Mohd Yunus, Muhammad Hakimi Tew Abdullah, Mohd Hilmi Abu Bakar, Nurul Atiqah Mohd Azlan, Aini Faezah Ramlan

To Link this Article: http://dx.doi.org/10.6007/IJARBSS/v8-i10/4785 DOI: $10.6007 /$ IJARBSS/v8-i10/4785

Received: 21 Sept 2018, Revised: 17 Oct 2018, Accepted: 27 Oct 2018

Published Online: 03 Nov 2018

In-Text Citation: (Ridzuan et al., 2018)

To Cite this Article: Ridzuan, A. R., Yunus, M. K. M., Abdullah, M. H. T., Bakar, M. H. A., Azlan, N. A. M., \& Ramlan, A. F. (2018). The Relationship between Students Satisfaction and their Academic Performance among Public Relations Degree Students in UiTM Alor Gajah Melaka. International Journal of Academic Research in Business and Social Sciences, 8(10), 874-882.

Copyright: (C) 2018 The Author(s)

Published by Human Resource Management Academic Research Society (www.hrmars.com)

This article is published under the Creative Commons Attribution (CC BY 4.0) license. Anyone may reproduce, distribute, translate and create derivative works of this article (for both commercial and non-commercial purposes), subject to full attribution to the original publication and authors. The full terms of this license may be seen

at: http://creativecommons.org/licences/by/4.0/legalcode

Vol. 8, No. 10, 2018, Pg. 874 - 882

http://hrmars.com/index.php/pages/detail/IJARBSS

JOURNAL HOMEPAGE

Full Terms \& Conditions of access and use can be found at http://hrmars.com/index.php/pages/detail/publication-ethics 


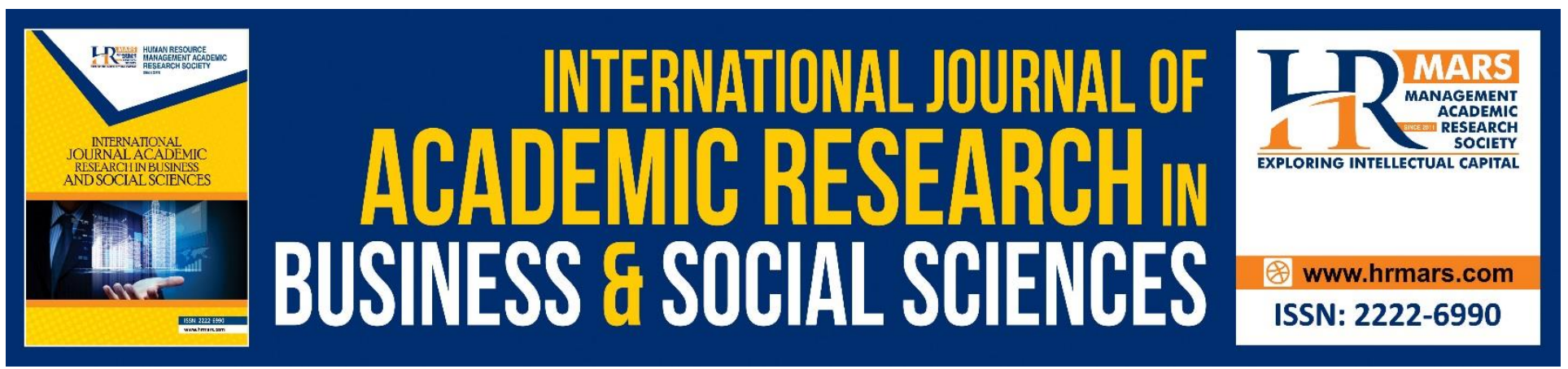

\title{
The Relationship between Students Satisfaction and their Academic Performance among Public Relations Degree Students in UiTM Alor Gajah Melaka
}

\author{
Abdul Rauf Ridzuan, Mohd Khairornizam Mohd Yunus, Muhammad \\ Hakimi Tew Abdullah, Mohd Hilmi Abu Bakar, Nurul Atiqah Mohd \\ Azlan, Aini Faezah Ramlan \\ Faculty of Communication \& Media Studies, Universiti Teknologi Mara Melaka
}

\section{Abstract}

A study was done to provide a professional evaluation of Public Relations degree students. Such a study had not been completed in the past and was needed to align student services with the mission, long-range goals, and strategic planning of the university. The researchers conducted a survey and distributed to all Public Relations students $(n=94)$ in UiTM Melaka. From the finding, the study demonstrated that relationship among UiTM staff, surrounding and facilities have are significant factors that effect on the students academic performance. In this study, the researchers used assimilation theory to describe satisfaction for PR degree students and the finding from this research showed that relationship between students and UiTM staff is the main contribution towards students academic performance.

Keywords: UiTM Alor Gajah, Melaka, Satisfaction, PR Degree, Academic Performance

\section{Introduction}

According to Hamre \& Pianta, (2001), students can engage academically and socially in a productive way when the teachers build a positive vibes and bond with the students. The classroom will be supportive space between the students and the teachers. The relationship between the teachers and the students for low income students are important in high school stems intervention studies aimed at improving academic outcome (Murray \& Malmgren, 2005). The relationship between the lecturers and the students are also important in institutions. This is because lecturers are the main reference for the student if the students are facing difficulties in their study. This relationship factor makes the researcher eager to know whether the lecturers and the students have a good relationship between them inside and outside of the classes. The reason that the researcher wanted to conduct this study is because of the curiosity to know whether the placement of PR Degree in UiTM Melaka is suitable or vice versa. Next, the researcher also wanted to identify whether the students are 
INTERNATIONAL JOURNAL OF ACADEMIC RESEARCH IN BUSINESS AND SOCIAL SCIENCES

Vol. 8, No. 10, Oct. 2018, E-ISSN: 2222-6990 @ 2018 HRMARS

equipped with the enough facilities. Finally, the researcher wanted to know the level of relationship between the academic as well as the non-academic staffs and the students in UITM Alor Gajah, Melaka.

\section{Problem Statement}

In September 2015, a total of 21 students were enrolled in UiTM Alor Gajah, Bachelor in Mass Communications with honors in the course of Public Relations. They were the first batch which was placed in UiTM Alor Gajah Melaka for a bachelor program in Public Relation after UiTM Shah Alam, Selangor. UiTM Arau, Perlis is one of the campuses which was once a campus placement program for Faculty of Communication and Media Studies. However, the placement of the program Communication and Media Studies at UiTM Arau, Perlis was no longer available as it has moved to UiTM Alor Gajah, Melaka. This is because the placement of Mass Communication students at UiTM Arau was not suitable. The students were facing difficulties to access with expert in mass communication. The researcher has carried out this research study with an objective to identify whether the placement of PR degree students in UiTM Alor Gajah will have competency as PR students in UiTM Shah Alam. In UiTM Shah Alam, the PR degree students can access better in terms of networking with practitioner. PR Degree students in Shah Alam have better access to get connected with public relations practitioners if they have to interview them for assignment purpose as Shah Alam was located in the Klang Valley area. The researcher is eager to know whether the PR Degree students in UiTM Alor Gajah are feeling comfortable enough to stay in the campus. According to Schneider (2002), clean, quiet, safe, comfortable, and healthy are the important components of successful teaching and learning. The researcher also carried out this research to determine whether PR Degree students in UiTM Melaka were equipped with adequate facilities to study in UiTM Melaka Alor Gajah. This is because facility is one of the important factors that contributes to the student's success.

\section{Students Satisfaction towards Learning In Uitm Cawangan Melaka}

\section{- Surronding Factor}

According to Badar, Kamruddin and Puteh (2005) that factors of attitude, polytechnic climate and lecturer teaching is one of the factors that most influence achievement student excellence. The environment refers to all the objects there is a circle around (Osman, 2004). In this study the environmental factors studied is class management. According to Hasmah Iberahim (2004), Class management refers to the comfort of a class structure ie arrangement of furniture, class facilities, student rankings and the comfort of students to study in solid state at a time. Attitude also factors that most influence achievement student academic performance. According to Anastasi (1976), attitude is a person's tendency to act with behavior certain behavior when dealing with something 
INTERNATIONAL JOURNAL OF ACADEMIC RESEARCH IN BUSINESS AND SOCIAL SCIENCES

Vol. 8, No. 10, Oct. 2018, E-ISSN: 2222-6990 @ 2018 HRMARS

stimulus. It is a person's mental process individuals who can determine the potential response of each individual to the environment.

\section{- Facilities}

As a growing university to world-class universities, many factors must be considered. One of them is of the aspect facilities and services provided by the university to students as a customer (W. Jaffar W. N. et al., 2005). Among them are lecture rooms / lectures / labs / workshops, libraries, cafeterias, international offices, sports and the university itself. To ensure students can learn in a good and comfortable environment as well teachers can communicate knowledge more effectively, so management, whether schools, Institutes of Higher Learning (IPTA) or the Institute of Studies Private High (IPTS), should provide infrastructures and facilities which are appropriate according to the course of the study (Selamat R., 2004). In accordance with the Lembaga Akreditasi Negara (2002) which has determined that each IPTS should have lecture rooms suitable for their size and complete with equipment to meet learning needs and laboratory / workshop / studio provided that it is also necessary and complete and comfortable for the teaching and learning process learning. Mok S. S. (2008) also stated that a conducive classroom must have basic equipment such as blackboard, board, and comfortable space, tables and chairs for teachers and pupils, wardrobes, decorated with preparation of reading materials, teaching materials and supporting equipment and is decorated with cheerfulness and cleanliness. Table structure and chair in the room is the best grade to facilitate the students to organize student-cantered learning activities and group activities. If it is convenient as stated can be provided as good as it may be giving satisfaction to the students and thus the teaching process and learning can run smoothly.

\section{- Relationship Among Uitm Staff}

Cho (2008) reported that students taking Life Skills courses at IPG Campus Raja Melewar, Seremban showed high interest in this subject and were satisfied with the physical conveniences as well as workshop equipment provided. They also agreed that they are easy to get the guidance from their lecturers to complete the course work, projects and assignments given. Students are also satisfied with the Integrated Living Skills Program proven to help teachers in teaching, helping to practice teaching methods and techniques, improving experience as well as improving new skills in instructors' teaching, enthusiasm and confidence. In Cho's (2008) study, there are some aspects that students are dissatisfied among them which are less lecturers provide practical training in practical work and students think references for the Life Skills subject is still lacking and needs to be added at the Institute Resource Centre. His study suggesting two improvements which are limited workshop equipment should be added and reference materials in Resource Centre should also be added. However, according to Yap Ming Hui (1994), the level of students' understanding does not depend on the teaching proficiency. The findings show that there is no significant correlation between lecturer's competence and academic performance. This illustrates that academic performance of students is not dependent on the relationship or the competence of the lecturers. 
INTERNATIONAL JOURNAL OF ACADEMIC RESEARCH IN BUSINESS AND SOCIAL SCIENCES

Vol. 8, No. 10, Oct. 2018, E-ISSN: 2222-6990 @ 2018 HRMARS

\section{Academic Performance}

According to Kamus Dewan (2005), achievement means what has been achieved or performance. Academics also relate to the academy (higher education center) and is characteristic or contains knowledge (high or profound). In other words, academic achievement focuses more on the grade obtained by a student in an occupation examination. If a student is achieving a good grade means that they have achieved excellence in the field academic and vice versa. In the context of this study, academic achievement refers to a decision CGPA (Average Value Collection) Public Relations students of the Faculty of Communication and Media Studies, UiTM, Alor Gajah Melaka. Suitable learning styles are essential to improve the academic achievements of the students (Chambers, 1991). Chambers thinks that students should be using the learning style as their strengths in the academic field. This is because the way in which the learning features will be causing students at all levels to be more motivated and beyond improving academic achievement. In addition, Dunn \& Dunn (1979) stated that when methods, resources, and programs are matched by characteristics student learning styles, then academic achievement and student attitudes will be increased. On the other hand, if the match between teaching and learning is not accordingly, academic achievement and attitudes are also deteriorating.

\section{Research Methodology}

This study employed the quantitative study approach (explanatory study) to identify the level relationship between students' satisfaction factor with academic performance. For sampling, by referring to Krejcie \& Morgan table, 94 PR degree students in UiTM Alor Gajah can be equal to 76 sample of respondents with 95\% confidence (The Research Advisors, 2006). The study involving all 94 respondents, selected through a purposive sampling. A cross sectional survey and structured questionnaire were used for data collection. The data were keyed in and analyzed by SPSS. (Abdul Rauf Ridzuan et al., 2015).

In this study, the sample size used was also determined by two technique namely Gower analysis (Erdfelder, Faul and Buchner, 1996), and Green (1991) recommendation on using Multiple Regression Analysis. Using GैPower analysis, specifically for $F$ - Test in Multiple Regression analysis, the total suggested sample is 78 (effect size $\mathrm{f}^{2}=0.15$ (medium); $\alpha=0.05$; power $=0.95$; number of predictors / independent variables $=5$ ). The value of Alpha and power were acceptable for social sciene research. GPower is a general power analysis program that perform high precision statistical power analyses for the most common statistical test in social science research. Moreover GtPower is design for sample size calculation based on specific statistical analysis used in the particular study (Erdfelder et al., 1996). The data was collected through a survey questionnaire. The method used to distribute the questionnaire is through online and self-administered questionnaires. A likert scale was used for the students to answer questions relating to the satisfaction factors. Data was key in and analyzed using SPSS version 20.

\section{Results and Discussions}

\section{Coefficients}


INTERNATIONAL JOURNAL OF ACADEMIC RESEARCH IN BUSINESS AND SOCIAL SCIENCES Vol. 8, No. 10, Oct. 2018, E-ISSN: 2222-6990 @ 2018 HRMARS

\begin{tabular}{|c|c|c|c|c|}
\hline \multirow{2}{*}{\multicolumn{2}{|c|}{ Model }} & $\begin{array}{c}\text { Standard } \\
\text { ized } \\
\text { Coefficie } \\
\text { nts } \\
\end{array}$ & \multirow[t]{2}{*}{$\mathrm{T}$} & \multirow[t]{2}{*}{ Sig. } \\
\hline & & Beta & & \\
\hline \multirow{4}{*}{1} & (Constant) & & 3.527 & .001 \\
\hline & MEAN_placement & -.253 & -3.268 & .002 \\
\hline & MEAN_facilities & .477 & 5.665 & .000 \\
\hline & MEAN_relationship & -.662 & -7.868 & .000 \\
\hline
\end{tabular}

Table 4.13 Multiple Regression

Dependent Variable: MEAN_AP

- $H_{1}$ There is a relationship between placement of PR Degree UiTM Melaka and academic performance of the PR Degree students.

Based on the multiple regression analysis mentioned earlier, there is significant negative relationship between placement and academic performance. Placement has a significant value of 0.002 which below the significant level of 0.05 . As placement decrease by 0.253 of a standard deviation, academic performance increases by one standard deviation. Thus, hypothesis is supported but at different direction of relationship. Based on the finding the right placement of PR Degree UiTM Melaka, will decrease the academic performance of the PR degree students. This direction affected due to the attitude of the students whom failed to manage their time when they were placed at the right placement especially at the urban area. According to Anastasi (1976), attitude is a person's tendency to act with behaviour certain behaviour when dealing with something stimulus. It is a person's mental process individuals who can determine the potential response of each individual to the environment.

- $\mathrm{H}_{2}$ There is a relationship between facilities and academic performance of the PR Degree students.

It has been shown by the regression analysis that facilities have a positive relationship towards academic performance with a $p$-value of $0.000(0.00 \%)$. The relationship is significant $(\beta=0.477, P=$ 0.00 ). Hence, there is a relationship between facilities and academic performance. Thus, the hypothesis is accepted. This is because, in accordance with the Lembaga Akreditasi Negara (2002) which has determined that each IPTS should have lecture rooms suitable for their size and complete with equipment to meet learning needs and laboratory / workshop / studio provided that it is also necessary and complete and comfortable for the teaching and learning process learning

- $\mathrm{H}_{3}$ There is a relationship between good relationship among UiTM staffs and academic performance of PR Degree students.

Based on the multiple regression analysis mentioned earlier, there is negative relationship between relationship among UiTM staffs and academic performance and it is significant $(\beta=-.662, P=0.00)$. Relationship has a significant value of 0.00 which below the significant level of 0.05 . As relationship decrease by 0.662 of a standard deviation, academic performance increase by one standard 
deviation. Thus, hypothesis is supported but at different direction of relationship. Based on the finding increase in relationship students with academic and non-academic staffs will decrease the academic performance of the PR Degree students.

However, the findings obtained by Siti Hadijah Atan (2004) in the study have stated that although there is a significant relationship, but the relation between the lecturer's ability and the understanding of the students towards learning does not contribute much to the students' academic performance. In addition, according to Yap Ming Hui (1994), the level of students' understanding does not depend on the teaching proficiency. The findings show that there is no significant correlation between lecturer's competence and academic performance. This illustrates that academic performance of students is not dependent on the relationship or the competence of the lecturers.

\section{Conclusion}

This research is conducted to study the student satisfaction and academic performance among PR Degree students at UiTM Alor Gajah, Melaka. There are three independent variables which are placement, facilities and relationship while academic performance acts as dependent variable. Based on the findings, it was found that all the variables proposed are related to the academic performance of PR students at UiTM Alor Gajah Melaka. Based on the findings, the most students' satisfaction factor that contribute to academic performance is relationship among UiTM staff in Alor Gajah Melaka. Hence, from the finding it was said that PR degree students in UiTM Alor Gajah Melaka are more satisfied with the relationship among the academic and non-academic staff in UiTM Melaka. Cho (2008), agreed that students are easy to get the guidance from their lecturers to complete the course work, projects and assignments given. The second factor that impact the students' satisfaction factor with academic performance is facilities. UiTM Alor Gajah, Melaka have to provide or to maintain a good facilities for the students to make sure that they can increase their academic performance. The last factor that give impact to the academic performance is right placement. The findings indicated that the right placement of students are important to increase the students' academic performance.

\section{Acknowledgement}

Researchers would like to say thank you to Deputy Rector of Research in UiTM Cawangan Melaka, Associate Prof Dr Shafinar Ismail and Melina Mahpuz, Deputy Dean of Research and Industry Linkage from Faculty of Communication \& Media Studies, UiTM Shah Alam for their encouragement and motivation to do this research.

\section{Corresponding Author}

Abdul Rauf Ridzuan (PhD), Faculty of Communication \& Media Studies, UiTM Cawangan Melaka, Malaysia. Email: abdulrauf@melaka.uitm.edu.my

\section{References}

Badar, A. R. \& Kamaruddin, N. A. Puteh, S. (2005). Faktor-Faktor Yang Mempengaruhi Pencapaian Pelajar Dalam Menguasai Mata Pelajaran Kejuruteraan Di Politeknik- Politeknik Kementerian 
INTERNATIONAL JOURNAL OF ACADEMIC RESEARCH IN BUSINESS AND SOCIAL SCIENCES Vol. 8, No. 10, Oct. 2018, E-ISSN: 2222-6990 @ 2018 HRMARS

Pengajian Tinggi Malaysia. Prosiding seminar pendidikan JJPG 2005. Fakulti Pendidikan Teknikal Kolej Universiti Teknologi Tun Hussein Onn

Boon, C. K. (2008). Pelaksanaan kurikulum Kemahiran Hidup (minor) di Jabatan Kajian Sosial, Institut Perguruan Raja Melewar, Seremban. Jurnal Melewar 12,52-65. Seremban: Penerbitan IPG Kampus Raja Melewar.

Chambers, B., \& Abrami, C.P. (1991). The Relationship Between Student TeamLearning Outcome and Achievement, Causal Attributions and Affect. Educational Psychology. 83: 140146.

Dunn, R. \& Dunn, K. (1979). Learning Styles/Teaching Styles: Should they.....can they be matched?. Educational Leadership. January, 238-244.

Hamre, B. K., \& Pianta, R. C. (2001). Early teacher-child relationships and the trajectory of children's school outcomes through eighth grade. Child Development, 72(2), 625 638.

Kamus, D. (2005). Edisi keempat. Kuala Lumpur, Dewan Bahasa dan Pustaka.

Lembaga Akreditasi Negara (2002). "Garis Panduan Kriteria dan Standard Kursus Pengajian IPTS". Lembaga Akreditasi Negara.

Mok, S. S. (2008). Ilmu Pendidikan untuk KPLI (Sek. Rendah: Komponen 1 \& 2) Psikologi Pendidikan \& Pedagogi. Kumpulan Budiman Sdn. Bhd., Subang Jaya.

Murray, C., \& Malmgren, K. (2005). Implementing a teacher-student relationship program in a highpoverty urban school: Effects on social, emotional, and academic adjustment and lessons learned. Journal of School Psychology, 43(2), 137-152.

Schneider, M. (2002), Do School Facilities Affect Academic Outcomes?, National Clearinghouse for Educational Facilities. Retrieved from:http://www.ncef.org/pubs/outcomes.pdf

Selamat. R., Ungku Ahmad. U. N., Abd Razak. N. Z., Ali. L., Abd Aziz. A., SheikhAhmad. F. dan Ahmad Khalid. A. (2004). Kajian ke atas Persekitaran Pengajaran dan Pembelajaran Fakulti Pengurusan dan Pembangunan Sumber Manusia: Ke Arah Pembentukan Persekitaran yang Optimum dalam Mencapai Kecemerlangan Pengajaran dan Pembelajaran. Vot Penyelidikan 75012. Universiti Teknologi Malaysia.

Atan, S. H., (2004). Hubungan Antara Keupayaan Jurulatih Dengan Kefahaman Pelatih Terhadap Pembelajaran Bagi Program "Bina Insan Warga Industry" Di Syarikat

Excel Training \& Consultancy (M) Sdn. Bhd. UTM, Tesis ljazah Sarjana.

Hui, Y. M. (1994). Hubungan Antara Kecekapan Pelajar Dengan Tahap Kefahaman Peserta Untuk Program Latihan "The Habit Of Highly Effective People" Di Petronas Management Training Sdn. Bhd. UTM. Tesis ljazah Sarjana. 
INTERNATIONAL JOURNAL OF ACADEMIC RESEARCH IN BUSINESS AND SOCIAL SCIENCES Vol. 8, No. 10, Oct. 2018, E-ISSN: 2222-6990 @ 2018 HRMARS 